\title{
Pemanfaatan Limbah Sayuran untuk Meningkatkan Pertumbuhan Sapi Penggemukan di Lokasi Model Pertanian Bioindustri Kabupaten Tabanan, Bali
}

\section{(Utilization of Vegetables Waste to Inc rease Cattle Growth at the Location of Bioindustrial Agric ulture Model, Tabanan Regency, Bali)}

\author{
Budiari NLG, Kertawirawan A, Adijaya IN, Sugianyar IM \\ Balai Pengkajian Teknologi Pertanian Bali \\ Jl. By Pass Ngurah Rai, Pesanggaran, Denpasar Selatan \\ budiariluhde@yahoo.co.id
}

\begin{abstract}
Study of potency and utilization of vegetables waste for fattening cattle were carried out in the Labak Lestari group at Antapan Village, Baturiti District, Tabanan Regency, Bali from February - June 2019. Observations were done on 20 samples from 3 farmers as replications. The cattle fattening study used a completely randomized design (CRD) with 2 feed treatments and each treatment used 10 male Bali cattle (BW 250-300 $\mathrm{kg}$ ) as replications. The treatments were: $\mathrm{P} 1=$ group of cattle given $100 \%$ of forage +1 $\mathrm{kg}$ of rice bran/a cattle/day and P2 = group of cattle given $50 \%$ of forage $+50 \%$ of vegetables waste $+1 \mathrm{~kg}$ of rice bran/a cattle/day. The variables observed were daily body weight gain, feed consumption and feed conversion ratio and Revenue Cost ratio (R/C ratio) analysis. The vegetables plants which able to produce the highest waste were young harvested corn, spinach, cabbage, and broccoli with potential waste of them were $7,920 \mathrm{t}, 2,141 \mathrm{t}, 2,024 \mathrm{t}$ and $1,779 \mathrm{t}$ with farming feasibility scale averaging were $0.2 \mathrm{ha}$, 0,17 ha, 0.10 ha and 0.12 ha.The potential of vegetables waste as animal feed as much as $15,643 \mathrm{t}$ capable to provide feed for 6 cattle which its weight about $150-200 \mathrm{~kg}$ for 6 months. Cattle of P2 treatment produced daily body weight gain (ADG) $0.55 \mathrm{~kg} / \mathrm{head} / \mathrm{day}$ with feed conversion ratio 7.60. These values were significantly higher $(\mathrm{P}<0.05)$ than $\mathrm{P} 1$. The utilization of vegetables waste can increase income up to Rp. 850,340. In conclusion vegetable waste increased significantly ADG and farmer's income. Vegetable waste was feasible to be applied by farmers.
\end{abstract}

Key words: Vegetables waste, biomass, feed, fattening cattle

\begin{abstract}
ABSTRAK
Studi tentang pemanfaatan limbah sayuran untuk meningkatkan pertumbuhan sapi penggemukan telah dilaksanakan di kelompok Labak Lestari Desa Antapan, Kecamatan Baturiti, Kabupaten Tabanan, Bali dari bulan Februari - Juni 2019. Kajian ini menghitung biomasa total tanaman sayuran, yang dapat dijual per satuan luas terhadap hasil ekonomis dan limbah sayuran. Pengamatan dilakukan pada 20 sampel di 3 petani sebagai ulangan. Kajian penggemukan sapi menggunakan Rancangan Acak Lengkap (RAL) dengan 2 perlakuan menggunakan 10 ekor sapi Bali jantan dengan (bobot badan awal 250-300 kg) sebagai ulangan. Perlakuan pakan yang diujikan: P1 = Kelompok sapi diberikan $100 \%$ hijauan + dedak padi 1 kg/ekor/hari dan P2 = Kelompok sapi diberikan $50 \%$ hijauan $+50 \%$ limbah sayur + dedak padi $1 \mathrm{~kg} / \mathrm{ekor} / \mathrm{hari}$. Variabel diamati yaitu
\end{abstract}


pertambahan berat badan, konsumsi ransum dan rasio konversi pakan, serta analisis revenue cost ratio ( $\mathrm{R} / \mathrm{C}$ ratio). Tanaman sayuran yang menghasilkan limbah tertinggi yaitu jagung panen muda, bayam, kol, dan brokoli dengan potensi limbah masing-masing 7,920 t, 2,141 t, 2,024 t dan 1,779 t dengan skala usahatani rata-rata 0,2 ha, 0,17 ha, 0,10 ha dan 0,12 ha. Potensi limbah sayuran sebagai pakan ternak sebanyak $15.643 \mathrm{t}$ dapat menyediakan pakan selama 6 bulan untuk 6 ekor ternak sapi dengan berat badan $150 \mathrm{~kg}$ - $200 \mathrm{~kg}$. Sapi yang mendapatkan perlakuan P2 menghasilkan pertambahan berat badan $(0,55 \mathrm{~kg} / \mathrm{ekor} / \mathrm{hari})$ dan rasio konversi pakan $(7,60)$ nyata lebih tinggi $(\mathrm{P}<0,05)$ dari $\mathrm{P} 10$. Pemberian limbah sayuran meningkatkan pendapatan sebesar Rp. 850.340. Limbah sayuran dapat meningkatkan pertambahan berat badan harian, pendapatan dan pemberian limbah sayuran layak diterapkan oleh peternak.

Kata kunci: Potensi, limbah sayur, pakan, sapi penggemukan

\section{PENDAHULUAN}

Ternak sapi merupakan salah satu komoditas strategis nasional dalam rangka mewujudkan ketahanan pangan yang berbasis sumberdaya lokal. Kebutuhan sapi bakalan akan terus meningkat seiring dengan meningkatnya kebutuhan daging masyarakat. Upaya meningkatkan produksi daging harus dilakukan secara maksimal untuk mengurangi ketergantungan impor, dengan cara optimalisasi pemanfaatan sumber daya lokal seperti halnya penyediaan pakan.

Salah satu upaya yang dapat dilakukan untuk mensukseskan program tersebut adalah dengan meningkatkan populasi dan produktivitas ternak sapi. Peningkatan populasi sangat berhubungan dengan penyediaan hijauan pakan, karena pakan merupakan faktor utama yang berpengaruh pada peningkatan produktivitas ternak sapi. Keberhasilan suatu peternakan sangat dipengaruhi oleh kualitas dan kuantitas pakan yang diberikan. Matondang \& Rusdiana (2013) melaporkan bahwa ketersediaan pakan perlu dijamin untuk mendukung upaya peningkatan produktivitas, populasi serta skala usaha pembibitan dan penggemukan sapi.

Produktivitas ternak di tingkat petani pada saat ini mengalami penurunan karena faktor pakan. Sempitnya lahan untuk mengembangkan hijauan pakan disebabkan oleh adanya alih fungsi lahan untuk sektor industri atau perumahan. Pakan yang diberikan pada ternak juga umumnya sangat tergantung pada musim. Setyawan et al. (2017) melaporkan bahwa turunnya kadar nutrisi pakan hijauan, seperti energi, protein, dan mineral, akibat kekurangan air pada musim kemarau menyebabkan penurunan konsumsi pakan yang berakibat menurunnya bobot badan ternak. Budiari et al. (2014) melaporkan pertumbuhan sapi pembesaran di tingkat petani dengan pakan seadanya menghasilkan pertambahan berat badan 0,32 kg/hari.

Pada pola pemeliharaan yang masih tradisional, dengan pemberian pakan seadanya menghasilkan pertambahan bobot badan sapi rata-rata sekitar 290 gram/ekor/hari (Yuliani et al. 2016) sedangkan (Yasa et al. 2016) melaporkan bahwa penurunan produktivitas ternak sapi menyebabkan usaha sapi penggemukan ditinggalkan oleh peternak. Tangendjaja (2009) melaporkan bahwa pakan yang berfluktuatif dengan kualitas hijauan atau limbah pertanian bervariasi sehingga sulit menghasilkan ransum yang konsisten, sehingga untuk meningkatkan produktivitas ternak sapi perlu adanya upaya untuk memenuhi kebutuhan pakannya baik secara kualitas maupun kuantitas. 
Kecamatan Baturiti, Kabupaten Tabanan, Provinsi Bali merupakan salah satu sentra sapi penggemukan dan berdasarkan Pergub Bali No. 9 th. 2013, ditetapkan sebagai kawasan sentra produksi komoditas hortikultura, khususnya sayuran dataran tinggi. Sebagai daerah penghasil sayur, potensi limbah sayuran sebagai pakan ternak belum dimanfaatkan secara optimal, karena adanya penggunaan pupuk kimia dalam budidaya sayuran. Sementara ini limbah sayuran dibuang sebagai sampah dan sebagian kecil dimanfaatkan untuk pupuk tanaman.

Melalui kegiatan model pertanian bioindustri yang berorientasi pada penekanan usahatani ramah lingkungan serta proses biologis dalam berbagai tahap proses produksi, maka proses pengolahan produk utama maupun hasil samping/limbah dilakukan secara optimal oleh petani, sehingga akan meningkatkan nilai tambah dan usahatani menjadi lebih efisien (Sabrina 2012). Terlaksananya model pertanian bio industri berdampak positif dilihat dari sisi ekonomi dan lingkungan (Manurung 2013). Selain dari aspek lingkungan, dari aspek sosial model pertanian bioindustri berpotensi menyerap tenaga kerja. Penggunaan pupuk kimia dapat diturunkan dan diganti dengan pupuk organik, dengan demikian limbah sayuran yang kurang berguna menjadi lebih berdaya guna untuk menggantikan sebagian rumput sebagai pakan ternak.

\section{MATERI DAN METODE}

Kajian ini dilaksanakan di Kelompok Ternak Labak Lestari, Desa Antapan, Kecamatan Baturiti, Kabupaten Tabanan dari bulan Februari sampai Juni 2019.

\section{Menghitung biomassa sayuran}

Biomasa tanaman sayuran dihitung dengan melakukan ubinan per satuan luas sesuai dengan jarak tanam tanaman sayuran. Perhitungan biomassa dilakukan terhadap hasil ekonomis tanaman dan limbah yang dihasilkan per satuan luas tanam dengan formula:

- Biomasa total $(\mathrm{kg})=$ Rata-rata berat total/tanaman $(\mathrm{kg} / \mathrm{tan}) \mathrm{x}$ jumlah populasi (tan)

- Hasil ekonomis (kg) = Rata-rata hasil ekonomis/tanaman (kg) x jumlah tanaman (tan)

- Hasil limbah/berangkasan (kg) = Rata-rata berat berangkasan/tanaman (kg) $\mathrm{x}$ jumlah populasi (tan)

Rata-rata variabel dihasilkan dari pengamatan terhadap 20 tanaman sampel di 3 petani sebagai ulangan, sedangkan jumlah tanaman per satuan luas dihasilkan dari perhitungan luas tanaman dibagi dengan jarak tanam tanaman dikurangi dengan lahan yang tidak ditanam untuk selokan.

Keterangan:

- Biomasa total = berat segar total tanaman diatas tanah

- Hasil ekonomis = bagian tanaman yang dijual/dipasarkan

- Hasil limbah = sisa tanaman diatas tanah 


\section{Penggemukan sapi}

Kajian ini menggunakan Rancangan Acak Lengkap (RAL) dengan 2 perlakuan pakan dan tiap-tiap perlakuan menggunakan 10 ekor sapi bali jantan dengan bobot badan awal 250-300 kg sebagai ulangan. Total jumlah sapi yang akan diberikan perlakuan sebanyak 20 ekor. Penggemukan dilaksanakan selama 5 bulan. Perlakuan pakan yang diujikan adalah sebagai berikut:

1. $\mathrm{P} 1=$ Kelompok sapi yang diberikan $100 \%$ hijauan + dedak padi $1 \mathrm{~kg} / \mathrm{ekor} / \mathrm{hari}$.

2. $\mathrm{P} 2$ = Kelompok sapi yang diberikan $50 \%$ hijauan $+50 \%$ limbah sayur + dedak padi $1 \mathrm{~kg} / \mathrm{ekor} / \mathrm{hari}$.

Hijauan yang diberikan terdiri dari rumput lapang dan rumput gajah, sebanyak $10 \%$ dari berat badan. Bahan yang dipergunakan dalam penelitian ini dedak padi, anti cacing, dan obat-obatan, sedangkan alat-alat yang dibutuhkan adalah terpal, sekop, ember dan timbangan digital.

\section{Variabel penelitian}

\section{Pertumbuhan sapi}

Pertumbuhan sapi atau pertambahan bobot badan sapi didasarkan atas bobot badan awal dan bobot akhir. Bobot badan awal diperoleh dengan cara melakukan penimbangan pada awal penelitian (sebelum diberikan perlakuan pakan); sedangkan bobot badan akhir diperoleh dengan melakukan penimbangan pada akhir penelitian (150 hari pemeliharaan). Penimbangan dilakukan setiap bulan untuk mengetahui pertambahan bobot badannya.

\section{Konsumsi ransum}

Konsumsi pakan dihitung setiap hari dengan mengurangi jumlah pakan yang diberikan dengan sisa pakan pada hari tersebut. Total konsumsi pakan diperoleh dengan cara menjumlahkan konsumsi pakan selama penggemukan dilakukan.

\section{Konversi ransum}

Konversi ransum atau Feed Conversion Ratio (FCR) dihitung dengan cara membagi jumlah ransum yang dikonsumsi dengan pertambahan berat badan selama penelitian.

\section{Analisis data}

Data yang diperoleh dianalisis dengan t-test, (Gomez \& Gomez 1995). Untuk mengetahui tingkat kelayakan usahatani dilakukan melalui analisis Revenue cost ratio ( $\mathrm{R} / \mathrm{C}$ ratio). Apabila $\mathrm{R} / \mathrm{C}$ ratio $>1$, usahatani tersebut layak untuk diusahakan, sebaliknya jika $\mathrm{R} / \mathrm{C}$ ratio $<1$, usahatani tersebut tidak layak diusahakan (Soekartawi 2002). 


\section{HASIL DAN PEMBAHASAN}

\section{Potensi limbah sayur sebagai pakan ternak}

Hasil perhitungan terhadap biomasa tanaman sayuran pada usahatani yang dilakukan di lokasi kajian menunjukkan bahwa tanaman jagung, bayam, kol dan brokoli memiliki potensi menghasilkan limbah yang tinggi dan dapat dimanfaatkan untuk pakan ternak. Tanaman jagung menghasilkan potensi limbah tertinggi sebesar 7,92 ton pada skala penanaman 0,2 ha, diikuti oleh limbah bayam $(2,141 \mathrm{t})$, kol (2,024 t) dan brokoli (1,778 t) dengan rata-rata penanaman 0,17 ha, 0,10 ha dan 0,12 ha (Tabel 1). Banyaknya limbah yang dihasilkan sangat dipengaruhi oleh habitus tanaman serta persentase limbah yang dihasilkan masing-masing komoditas selain juga dipengaruhi oleh luasan tanam masing-masing komoditas.

Tingginya penggunaan pupuk kimia menyebabkan limbah sayuran tidak dimanfaatkan untuk pakan ternak selama ini, kecuali limbah jagung. Adanya kegiatan bioindustri, dimana penggunaan pupuk kimia telah diganti dengan pupuk organik, peternak mulai memanfaatkan limbah sayuran untuk pakan ternak sapi. Dinata (2016) melaporkan bahwa melalui pertanian bioindustri mampu memaksimalkan produksi biomassa baik produk primer maupun limbah (by product) untuk menghasilkan bahan pangan, pakan, pupuk, energi, kimia, farmasi, sandang dan bioproduk dengan tetap menjaga keseimbangan agroekosistem. Lebih lanjut Yasa \& Adijaya (2017) melaporkan bahwa untuk menyediakan pakan secara berkelanjutkan perlu adanya usahatani yang berintegrasi antara sapi dengan tanaman.

Pada kajian ini integrasi sayuran dengan ternak sapi menghasilkan penyediaan pakan dari limbah sayuran sebanyak 15.643 ton per tahunnya mampu mensuplai pakan ternak sapi sebanyak 6 ekor untuk sapi dengan bobot badan 150-200 kg selama 6 bulan pemeliharaan. Budiari \& Yasa (2015) melaporkan bahwa limbah sayuran yang dicampur dengan jerami padi mampu menyediakan pakan sebanyak7.487,76 kg berpotensi memenuhi kebutuhan ternak sebanyak 2 ekor dengan rata-rata berat badan $300 \mathrm{~kg}$ selama 125 hari. Sudaratmaja (2010) melaporkan bahwa penggunaan biomasa sebagai pakan akan memanfaatkan sumber daya lokal dan peningkatan pendapatan.

Limbah sayuran (limbah jagung, bayam, wortel, kol dan brokoli) yang selama ini dibuang sebagai sampah ternyata memiliki kandungan protein lebih tinggi dari pakan hijauan. Hasil analisis proksimat dedak padi, hijauan dan limbah sayuran yang diberikan pada sapi penggemukan di kelompok Labak Lestari dapat dilihat pada Tabel 2.

\section{Pertumbuhan sapi penggemukan yang diberikan limbah sayuran}

Hasil kajian menunjukkan sapi yang diberikan pakan 50\% hijauan $+50 \%$ limbah sayuran + dedak padi $1 \mathrm{~kg} /$ ekor/hari menghasilkan pertambahan berat badan sebesar 0,55 kg/ekor/hari nyata lebih tinggi $(\mathrm{P}<0,05)$ dari kontrol (Tabel 3). Hal ini disebabkan karena kandungan gizi pakan menjadi meningkat dengan adanya campuran limbah sayuran yang diberikan pada ternak sapi. Tabel 2 menunjukkan kandungan gizi dari limbah sayur lebih tinggi dari hijauan, yaitu kandungan protein kasar limbah sayuran 14,31\%, sedangkan kebutuhan minimal protein kasar untuk ternak sapi penggemukan sebesar $12 \%$ (Zulbardi et al. 2000). Oleh karena itu, untuk 
Tabel 1. Potensi limbah sayuran untuk pakan ternak sapi di Desa Antapan, Kecamatan Baturiti, Kabupaten Tabanan

\begin{tabular}{|c|c|c|c|c|c|c|c|c|}
\hline \multirow{2}{*}{ Komoditas } & \multicolumn{3}{|c|}{ Rata-rata berat/tanaman (kg) } & \multirow{2}{*}{$\begin{array}{c}\text { Jumlah } \\
\text { tanaman/ } \\
1.000 \mathrm{~m}\end{array}$} & \multirow{2}{*}{$\begin{array}{c}\text { Rata-rata luas } \\
\text { tanam/KK (m2) }\end{array}$} & \multicolumn{3}{|c|}{ Rata-rata berat/luas tanam (kg) } \\
\hline & Total & Ekonomis & Brangkasan & & & Total & Ekonomis & Brangkasan \\
\hline Bayam & 3,56 & 3,00 & 0,56 & 2.200 & 1.738 & 13.61 & 11.471 & 2.141 \\
\hline Kol & 2,63 & 1,71 & 0,92 & 2.200 & 1.000 & 5.786 & 3.762 & 2.024 \\
\hline Jagung & 1,55 & 0,35 & 1,20 & 3.300 & 2.000 & 10.23 & 2.310 & 7.920 \\
\hline Kol bunga & 0,89 & 0,49 & 0,40 & 2.500 & 740 & 1.647 & 907 & 740 \\
\hline Brokoli & 1,00 & 0,40 & 0,60 & 2.500 & 1.186 & 2.965 & 1.186 & 1.779 \\
\hline Emon & 0,03 & 0,01 & 0,02 & 30.000 & 357 & 348 & 134 & 214 \\
\hline Sayur hijau & 0,04 & 0,03 & 0,01 & 30.000 & 1.417 & 1.615 & 1.360 & 255 \\
\hline Sawi putih & 0,01 & 0,80 & 0,21 & 2.200 & 1.233 & 2.732 & 2.162 & 570 \\
\hline
\end{tabular}

Tabel 2. Hasil analisis proksimat hijauan dan limbah sayur yang diberikan pada penggemukan sapi di Desa Antapan, Kecamatan Baturiti Kabupaten Tabanan

\begin{tabular}{lccccc}
\hline \hline \multirow{2}{*}{ Uraian } & \multicolumn{3}{c}{ Kandungan Nutrien Bahan (\%) } \\
\cline { 2 - 6 } & BK & PK & LK & SK & TDN \\
\hline Dedak padi & 91,70 & 9,90 & 2,30 & 18,50 & 35,50 \\
Hijauan & 90,88 & 9,88 & 2,76 & 51,14 & 57,19 \\
Sayur hijau & 90,39 & 23,29 & 2,28 & 23,64 & 35,11 \\
Brokoli & 97,38 & 16,62 & 6,74 & 17,76 & 31,15 \\
Wortel & 96,74 & 19,47 & 5,53 & 26,30 & 60,20 \\
Jerami jagung segar & 21,70 & 9,70 & 2,20 & & \\
\hline
\end{tabular}

Hasil analisis proksimat Nutrisi Pakan Ternak, Lolit Sapi Potong, Grati, 2018 
memenuhi kebutuhan protein dari ransum yang diberikan pada ternak sapi perlu kombinasi antara hijauan, legum dan sumber energi. Budiari et al. (2016) melaporkan bahwa ternak sapi yang diberikan pakan campuran rumput lapang dengan rumput odot menghasilkan pertambahan berat badan $0,43 \mathrm{~kg} / \mathrm{hari}$.

Sugama et al. (2009) melaporkan sapi Bali yang diberikan pakan limbah sayuran ditambah $2 \mathrm{~kg} / \mathrm{ekor} / \mathrm{hari}$ dedak padi menghasilkan pertambahan berat badan 640 g/ekor/hari lebih tinggi dibandingkan dengan sapi yang hanya diberikan rumput. Perbedaan hasil kajian ini dengan penelitian terdahulu karena jenis hijauan dan lokasi penggemukan sapi yang berbeda.

Tabel 3. Pertumbuhan sapi penggemukan yang diberikan pakan limbah sayuran di Desa Antapan, Kecamatan Baturiti, Kabupaten Tabanan, tahun 2019

\begin{tabular}{lcc}
\hline \hline \multirow{2}{*}{ Uraian } & \multicolumn{2}{c}{ Perlakuan } \\
\cline { 2 - 3 } & $\mathrm{P} 1$ & $\mathrm{P} 2$ \\
\hline Berat badan awal (kg) & 269,00 & $270,42^{\mathrm{ns}}$ \\
Berat badan akhir (kg) & 318,33 & $333,50^{*}$ \\
Pertambahan berat badan (kg/hari) & 0,43 & $0,55^{*}$ \\
Konsumsi bahan kering ransum (kg/hari) & 4,81 & $4,18^{\mathrm{ns}}$ \\
FCR & 11,19 & $7,60^{*}$ \\
\hline
\end{tabular}

P1 = Kelompok sapi yang diberikan $100 \%$ rumput + dedak padi 1 kg/ekor/hari P2 $=$ Kelompok sapi yang diberikan $50 \%$ rumput $+50 \%$ limbah sayur + dedak padi 1 $\mathrm{kg} / \mathrm{ekor} / \mathrm{hari}$

Superskrip yang sama pada baris yang sama menunjukkan perbedaan yang tidak nyata $(\mathrm{P}>0,05)$

Konsumsi bahan kering ransum sapi yang diberikan perlakuan P0 lebih tinggi dari P1, namun secara statistik tidak menunjukan perbedaan yang nyata $(\mathrm{P}>0,05)$ (Tabel 3). Hal ini disebabkan karena kandungan serat kasar ransum P0, lebih tinggi dibandingan dengan P1 (Tabel 2) sehingga konsumsi bahan kering ransum lebih tinggi. Tillman et al. (1986) melaporkan bahwa kecernaan bahan kering ransum dipengaruhi oleh komposisi bahan penyusun ransum dan bentuk fisik ransum. Konsumsi ransum sangat dipengaruhi oleh palatabilitas pakan dan kandungan zat pakan yang menyusun ransum tersebut. Makin baik kualitas pakan yang diberikan yaitu dengan imbangan energi dan protein yang seimbang maka ternak akan mengkonsumsi pakan secukupnya. Mariam (2004) melaporkan bahwa jumlah konsumsi pakan merupakan faktor penentu yang paling penting dalam menentukan jumlah zat-zat makanan yang didapat oleh ternak.

Nilai konversi ransum untuk sapi yang diberikan perlakuan P1 lebih rendah dari P0 (Tabel 3). Hal ini disebabkan jumlah konsumsi pakan lebih sedikit menghasilkan peningkatan pertambahan berat badan yang lebih tinggi. Ini menunjukkan sapi yang diberikan pakan kombinasi hijauan dan limbah sayuran lebih efisien memanfaatkan pakan untuk pertumbuhannya. Semakin kecil rasio konversi pakan berarti semakin efisien pakan tersebut untuk menghasilkan pertambahan bobot badan (Mide 2007). Budiari el al. (2014) melaporkan bahwa sapi Bali yang diberikan limbah jagung manis + polard $1 \mathrm{~kg} / \mathrm{ekor} / \mathrm{hr}+$ pemacu tumbuh $1 \mathrm{ml} / 90$ berat badan menghasilkan konversi pakan 8,46 lebih rendah dari sapi yang diberikan pakan hijauan. 


\section{Analisis usahatani penggemukan sapi}

Analisa usahatani yang dilakukan di kelompok Labak Lestari memberikan informasi tentang seberapa besar usahatani penggemukan sapi dengan pemberian limbah sayur memberikan keuntungan, efisiensi modal, titik impas dan efisiensi usaha yang dilakukan. Hasil perhitungan sapi yang diberikan perlakuan P1 membutuhkan modal usaha yang lebih tinggi sebesar Rp. 56.800,- dibandingkan dengan P0 (Tabel 4) ini disebabkan karena berat badan bibit yang lebih berat sehingga harga bibit lebih mahal yang menyebabkan biaya produksi menjadi lebih tinggi dibandingkan dengan perlakuan P0.

Tabel 4. Hasil analisis usahatani sapi penggemukan yang diberikan pakan limbah sayuran di Desa Antapan, Kecamatan Baturiti, Kabupaten Tabanan, Tahun 2019

\begin{tabular}{|c|c|c|c|c|}
\hline \multirow{2}{*}{ Input Produksi } & \multirow{2}{*}{ Volume } & \multirow{2}{*}{ Satuan } & \multicolumn{2}{|c|}{ Perlakuan } \\
\hline & & & P0 & $\mathrm{P} 1$ \\
\hline - Berat awal bibit & 1 & ekor & 269 & 270,42 \\
\hline $\begin{array}{l}\text { Bibit (harga per kg hidup @ Rp } \\
\text { 40.000,-) }\end{array}$ & 40.000 & Rp. & 10.760 .000 & 10.816 .800 \\
\hline \multicolumn{5}{|l|}{ Pakan } \\
\hline $\begin{array}{l}\text { - P0 dan P1 = Dedak padi } \\
@ R p 3.500,-/ k g\end{array}$ & 150 & hari & 525.000 & 525.000 \\
\hline Obat-obatan dan Vitamin & 1 & kali & 50.000 & 50.000 \\
\hline Tenaga kerja @Rp.80.000,-/hari & 18,75 & $\mathrm{OH}$ & 1.500 .000 & 1.500 .000 \\
\hline Penyusutan kandang & 10 & tahun & 208 & 208 \\
\hline Total Input (Rp) & & & 12.835.208 & 12.892 .008 \\
\hline \multicolumn{5}{|l|}{ Pendapatan : } \\
\hline - Berat badan akhir ternak (kg) & 1 & $\mathrm{~kg}$ & 318 & 334 \\
\hline $\begin{array}{l}\text { Penjualan ternak @ Rp. } \\
\text { 42.000/kg }\end{array}$ & 42.000 & Rp. & 13.369 .860 & 14.007 .000 \\
\hline $\begin{array}{l}\text { - Produksi kotoran kering (Siap } \\
\text { dijual) }\end{array}$ & 450 & $\mathrm{~kg}$ & 450 & 450 \\
\hline $\begin{array}{l}\text { Penjualan kotoran @ Rp.700,- } \\
\text { /kg }\end{array}$ & 1 & $\mathrm{Rp}$ & 315.000 & 315.000 \\
\hline Total Penerimaan (Rp) & 1 & Rp & 13.684 .860 & 14.322 .000 \\
\hline Keuntungan (Rp) & & & 849.652 & 1.429 .992 \\
\hline R/C Ratio & & & 1,07 & 1,11 \\
\hline B/C Ratio & & & 0,07 & 0,11 \\
\hline Titik Impas Produksi (TIP) kg & & & 306 & 307 \\
\hline $\begin{array}{l}\text { Titik Impas Harga (TIH ) } \\
\text { Rp/kg) }\end{array}$ & & & 40.320 & 38.657 \\
\hline
\end{tabular}


Berdasarkan nilai jual pada akhir penggemukan, untuk sapi yang mendapat perlakuan pakan P1 memberikan keuntungan lebih tinggi dengan R/C 1,11 seperti yang terlihat pada Tabel 4. Meningkatnya keuntungan pada P1 disebabkan karena peningkatan pertumbuhan yang lebih tinggi sehingga memberikan berat akhir yang paling tinggi. Secara ekonomi pemberian pakan limbah sayur memberikan keuntungan dan peningkatan pendapatan bagi peternak, disamping itu limbah sayur yang selama ini tidak dimanfaatkan dapat dimanfaatkan sebagai pakan ternak.

Harga jual diasumsikan Rp. 42.000,- maka seluruh biaya produksi yang dikeluarkan akan tertutupi pada berat badan sapi masing-masing 306 kg (P0) dan 307 kg (P1). Semakin tinggi biaya produksi yang dikeluarkan dalam proses penggemukan seperti penggunaan tenaga kerja dan sarana produksi akan menyebabkan semakin tinggi berat badan sapi yang perlukan untuk menutupi seluruh biaya produksi. Hasil analisis yang dilakukan menunjukkan berat badan akhir perlakuan P0 (318 kg) dan P1 (334 kg) lebih besar dibandingkan dengan titik impas produksi, yang mengindikasikan bahwa selisih berat badan tersebut dikalikan dengan harga jual merupakan keuntungan usaha penggemukan yang dilakukan.

Hasil penelitian menunjukkan titik impas harga menunjukkan keadaan dimana usaha penggemukan yang dilakukan dapat menutupi semua biaya yang dikeluarkan pada usaha penggemukan yang dilakukan. Hasil perhitungan diperoleh titik impas harga sapi yang diberikan perlakuan P0 Rp. 40.320,- dan P1 Rp. 38.657,-. Hasil ini mengindikasikan bahwa tingkat harga yang diperoleh dari penjualan lebih tinggi (Rp. 42.000) dibandingkan perhitungan titik impas harga. Titik impas harga mencerminkan harga minimum, dimana tidak terjadi keuntungan atau kerugian (R/C =1). Selisih harga jual dengan perhitungan titik impas harga merupakan keuntungan yang diterima dalam usaha penggemukan yang dilakukan.

\section{KESIMPULAN}

Pemberian limbah sayuran pada ternak sapi berpengaruh positif terhadap pertambahan berat badan harian, konversi ransum dan pendapatan peternak. Berdasarkan hasil tersebut pemberian limbah sayuran untuk penggemukan sapi layak untuk diterapkan.

\section{UCAPAN TERIMA KASIH}

Terimakasih penulis ucapkan kepada Bapak I Nyoman Sutresna dan Bapak I Wayan Arta Negara yang telah membantu dalam pengamatan dan pengumpulan data di lapangan sehingga makalah ini dapat diselesaikan tepat pada waktunya.

\section{DAFTAR PUSTAKA}

Budiari NLG, Yasa IMR, Kertawirawan IPA. 2014. Peningkatan produktivitas sapi Bali dara dengan pemanfaatan limbah jagung manis. Prosiding Seminar Nasional Pembangunan Nasional Berbasis Teknologi dan Sumberdaya Lokal. Jember (Indonesia): Kerjasama LPPM dengan Fakultas Pertanian, Universitas Muhammadiyah Jember. hlm. 54-58.

Budiari NLG, Yasa IMR. 2015. Potensi pemanfaatan tanaman lokal, limbah sayuran, dan jerami padi untuk mendukung penggemukan sapi Bali di Kecamatan Baturiti. 
Prosiding Seminar Nasional Peran Inovasi Teknologi dan Jasa Lingkungan Budaya Subak dalam Mendukung Ketahanan Pangan Nasional. Denpasar (Indonesia): Balai Pengkajian Teknologi Pertanian Bali, Badan Penelitian dan Pengembangan Pertanian Kementerian Pertanian Bekerjasama dengan Universitas Hindu Indonesia. hlm. 140-146.

Budiari NLG, Yasa IMR, Adijaya IN. 2016. Substitusi rumput lapang dengan gajah odot untuk meningkatkan pertumbuhan sapi bali bakalan. Prosiding. Seminar Nasional Pertanian. Mataram (Indonesia): Fakultas Pertanian, Universitas Mataram. hlm. 608-615.

Bogart R, Taylor RE. 1983. Scientific farm animal production. 2nd ed. Minnesota (USA): Burgess Publishing Company.

Dinata AANNS. 2016. Peran mikroorganisme dalam upaya pengembangan model pertanian bio industri pada agroekosistem perkebunan kopi di Provinsi Bali. Prosiding Seminar Nasional Pertanian. Mataram (Indonesia): Fakultas Pertanian, Universitas Mataram. hlm. 31-38.

Gomez KA, Gomez AA. 1995. Prosedur statistik untuk penelitian. Syamsudin E, Baharsyah JS, penterjemah. Jakarta (Indonesia): Universitas Indonesia Press.

Mariam T. 2004. Perbedaan pertambahan bobot badan, konsumsi dan efisiensi pakan antara sapi jantan PO dengan Fries Holland dalam kondisi peternakan rakyat [Skripsi]. [Bandung (Indonesia)]: Fakultas Peternakan, Universitas Padjajaran.

Matondang RH, Rusdiana S. 2013. Langkah-langkah strategis dalam mencapai swasembada daging sapi/kerbau 2014. Jurnal Litbang Pertanian. 32:131-139.

Manurung R. 2013. Pengembangan sistem pertanian bio industri berkelanjutan. “Sosialisasi Strategi Induk Pembangunan Pertanian (SIPP) 2013 -2045”. Medan 13 Nopember 2013.

Mide MZ. 2007. Konversi ransum dan income over feed and chick cost broiler yang diberikan ransum mengandung berbagai level tepung rimpang temulawak (Curcumin xanthoriza Oxb). Buletin Nutrisi dan Makanan Ternak Universitas Hasanuddin Makassar. 6:21-26.

Sabrina NM. 2012. Bio Industri: Definisi dan ruang lingkup. Malang (Indonesia): Lab Bio Industri, Jurusan Industri Pertanian, Universitas Brawijaya.

Setyawan S, Hidayat IR, Yulistiani D. 2017. Ketersediaan hasil samping tanaman tebu di Provinsi Jawa Barat dalam mendukung ketersediaan pakan ternak ruminansia. Prosiding. Seminar Nasional Penyediaan Inovasi dan Strategi Pendampingan untuk Pencapaian Swasembada Pangan. Semarang (Indonesia): Balai Besar Pengkajian dan Pengembangan Teknologi Pertanian Bekerjasama dengan Balai Pengkajian Teknologi Pertanian Jawa Tengah, Fakultas Pertanian dan Bisnis UKSW Salatiga. hlm. 1051-1058.

Soekartawi. 2002. Analisis usahatani. Jakarta (Indonesia): UI Press, Universitas Indonesia.

Siregar SB. 2008. Penggemukan sapi. Jakarta (Indonesia): Penebar Swadaya.

Soeparno. 1992. Ilmu dan teknologi daging. Cetakan kedua. Yogyakarta (Indonesia): Universitas Gadjah Mada.

Sudaratmaja IGAK. 2010. Strategi pembangunan pertanian terintegrasi mendukung pertanian organik. Prosiding Seminar Nasional Isu Pertanian Organik dan 
Tantangannya. Bali (Indonesia): Balai Besar Pengkajian dan Pengembangan Teknologi Pertanian, Program Studi Pasca Sarjana Ilmu Lingkungan Universitas Udayana dan Balai Pengkajian Teknologi Pertanian Bali. hlm. 16-18.

Sugama IN, Londra IM, Sutami IP. 2009. Pengaruh probiotik bio-cas terhadap pertumbuhan sapi bali yang diberi pakan rumput dan limbah sayuran. Prosiding Inovasi Untuk Petani dan Peningkatan Daya Saing Produk Pertanian. Malang (Indonesia): Balai Pengkajian Teknologi Pertanian Jawa Timur dengan FEATI dan Dinas Pertanian Provinsi Jawa Timur. hlm. 374-378.

Tangendjaya B. 2009. Teknologi pakan dalam menunjang industri peternakan di Indonesia. Majalah Pengembangan Inovasi Pertanian. 2:193-194.

Tillman AD, Hartadi H, Reksohardiprodja S, Soekamto L. 1986. Ilmu makanan ternak dasar. Yogyakarta (Indonesia): Gadjah Mada University Press.

Yasa IMR, Adijaya IN, Budiari NLG. 2016. Substitusi rumput lapang dengan gajah odot untuk meningkatkan pertumbuhan sapi bali bakalan. Prosiding Seminar Nasional Pertanian. Mataram (Indonesia): Fakultas Pertanian, Universitas Mataram. hlm. 690-699.

Yasa IMR, Adijaya IN. 2017. Potensi dampak negatif alih fungsi lahan sawah terhadap produksi pakan untuk keberlanjutan pengembangan ternak sapi di Kabupaten Tabanan. Prosiding Seminar Nasional Inovasi Teknologi Pertanian Spesifik Lokasi. Banjarbaru (Indonesia): Balai Besar Pengkajian dan Pengembangan Teknologi Pertanian. hlm. 1395-1405.

Yuliani D, Utina U, Ratnawati S. 2016. Sistem integrasi padi ternak untuk mewujudkan kedaulatan pangan. Prosiding Seminar Nasional Pertanian Lahan Kering. Kupang (Indonesia): Balai Besar Pengkajian dan Pengembangan Teknologi Pertanian bekerjasama dengan Universitas Nusa Cendana. hlm. 309-322.

Zulbardi M, Kuswandi, Martawidjaja M, Thalib C, Wiyono DB. 2000. Daun gliricidia sebagai sumber protein pada sapi potong. Prosiding Seminar Nasional Peternakan dan Veteriner. Bogor (Indonesia): Pusat Penelitian dan Pengembangan Peternakan. hlm. 233-241. 